\title{
The relationships between bariatric surgery and sexual function: current evidence based medicine
}

\author{
Shengzhuo Liu ${ }^{1 \dagger}$, Dehong Cao ${ }^{1 \dagger}$, Zhengju Ren ${ }^{1 \dagger}$, Jinze $\mathrm{Li}^{2}$, Lei Peng ${ }^{2}$, Qin Zhang ${ }^{3}$, Bo Cheng ${ }^{1}$, Zheyu Cheng ${ }^{1}$, \\ Jianzhong $\mathrm{Ai}^{1}$, Xiaonan Zheng ${ }^{1}$, Liangren Liu ${ }^{1 *}$ and Qiang Wei ${ }^{1^{*}}$ (D)
}

\begin{abstract}
Background: Controversy remains despite several studies have discussed the role of bariatric surgery in improving male's sexual function. This study aims to evaluate the efficacy of bariatric surgery in promoting male's erectile function.

Methods: PubMed, EMbase, The Cochrane Library, CNKI and Clinical Trails.gov were searched from database inception to May 2019. The language of publication was limited in English. The International Index of Erectile Function (IIEF) score and Brief Male Sexual Function Inventory (BSFI) score were set as the primary outcome.

Results: Eleven studies with a total of 370 patients were enrolled in this meta-analysis. The results showed significant improvement in the IIEF score (erectile function: $\mathrm{MD}=5.33,95 \% \mathrm{Cl} 4.12-6.54$; intercourse satisfaction: $\mathrm{MD}=2.57,95 \%$ $\mathrm{Cl} 1.19-3.94$; orgasmic function: $\mathrm{MD}=0.50,95 \% \mathrm{Cl} 0.60-0.94$; overall satisfaction: $\mathrm{MD}=1.67,95 \% \mathrm{Cl} 0.78-2.56$; sexual desire: $\mathrm{MD}=1.27,95 \% \mathrm{Cl} 0.61-1.93$; total erectile function: $\mathrm{MD}=7.21,95 \% \mathrm{Cl} 4.33-10.10$ ) and the BSFI score (erection: $M D=2.53,95 \%$ Cl 2.39-2.67; ejaculation: $M D=1.40,95 \%$ Cl 1.28-1.51; desire: $M D=1.40,95 \%$ Cl 1.32-1.49; problem assessment: $\mathrm{MD}=2.20,95 \% \mathrm{Cl} 2.06-2.34$; sexual satisfaction: $\mathrm{MD}=0.70,95 \% \mathrm{Cl} 0.60-0.76$ ) in obese individuals after bariatric surgery.
\end{abstract}

Conclusions: This systematic review and meta-analysis indicated that bariatric surgery could be effective in promoting males's sexual function for obese individuals.

Keywords: Bariatric surgery, Obesity, Erectile function, Sexual function, Sex hormone, Meta-analysis

\section{Background}

Erectile dysfunction, one of the most complained problems during sexual intercourse, is defined as the inability to achieve or maintain an erection sufficient for satisfactory sexual performance [1], which has been paid more and more attention for its` association with poor quality of male's sexual life [2] and high prevalence.

\footnotetext{
* Correspondence: Liuliangren5-17@163.com; weiqiang339@126.com †Shengzhuo Liu, Dehong Cao and Zhengju Ren contributed equally to this work.

'Department of Urology, Institute of Urology, West China Hospital, Sichuan University, Chengdu, Sichuan, China

Full list of author information is available at the end of the article
}

Epidemiological studies indicated that in 1995 erectile dysfunction (ED) affected over 150 million men worldwide and the prevalence will reach 322 million by 2025 [3], which could be a great healthy burden to the society for its high prevalence in the general population and tight association with life quality impairment [4].

Obesity, especially morbid obesity, is associated with a broad range of medical and psychosocial comorbidities which impose a negative effect on patients' lives and health-care systems, including non-insulin dependent diabetes mellitus, coronary heart disease, stroke and hypertension [5-8]. Evidence from a large number of

(c) The Author(s). 2020 Open Access This article is licensed under a Creative Commons Attribution 4.0 International License, which permits use, sharing, adaptation, distribution and reproduction in any medium or format, as long as you give appropriate credit to the original author(s) and the source, provide a link to the Creative Commons licence, and indicate if changes were made. The images or other third party material in this article are included in the article's Creative Commons licence, unless indicated otherwise in a credit line to the material. If material is not included in the article's Creative Commons licence and your intended use is not permitted by statutory regulation or exceeds the permitted use, you will need to obtain permission directly from the copyright holder. To view a copy of this licence, visit http://creativecommons.org/licenses/by/4.0/ The Creative Commons Public Domain Dedication waiver (http://creativecommons.org/publicdomain/zero/1.0/) applies to the data made available in this article, unless otherwise stated in a credit line to the data. 
studies have shown relationships between obesity and derangements in sexual function [9-11]. It was reported that the occurrence of ED was higher in obese males than in those of normal weight [12]. Sarwer et al. [11] demonstrated in their study that $36 \%$ of men seeking bariatric surgery reported erectile dysfunction. Moore et al. [13] reported in their study $45 \%$ of obese men who seek weight reduction met diagnostic criteria of erectile dysfunction. Laumann et al. [4] reported in the United States that the prevalence of sexual dysfunction in general male population was $31 \%$.

Several managements have been introduced to deal with obesity. Dietary intervention, medications, physical exercise are widely used in case of mild and moderate obesity [14]. Meanwhile, bariatric surgery has become the most effective treatment strategy for morbid obese patients which can bring great weight reduction and is expected to ameliorate the comorbidities $[15,16]$. The bariatric surgical procedures, including gastric bypass, vertical sleeve gastrectomy, and biliopancreatic diversion, are recommended for class 2 obesity associated with comorbidities and for class 3 obesity (body index [BMI] $35-39.9 \mathrm{~kg} / \mathrm{m}^{2}$ and $>40 \mathrm{~kg} / \mathrm{m}^{2}$; respectively) [17].

As an effective procedure in promoting weight loss and improving obesity-related physical comorbidities, bariatric surgery is now widely performed on obese patients [18-21]. A number of studies have studied the effect of bariatric surgery on male's sexual function while the results are inconsistent. Significant improvement was observed in some studies but not in the other studies. Hence, we performed the systemic review and metaanalysis to investigate the efficacy of bariatric surgery in promoting male's sexual function.

\section{Methods}

Before conducting a systematic literature search, we formulated a protocol to standardize the process of literature review and data extraction which is agreed by all the authors.

\section{Inclusion and exclusion criteria}

Two independent reviewers separately assessed each study based on the inclusion and exclusion criteria to determine whether the study is eligible. Studies meeting the following criteria were included: (1) self-control study, (2) randomized controlled trials which use bariatric surgery as intervention, (3) at least one of the erectile function assessment score system (IIEF score and BSFI score) was assessed and reported. For exclusion, we eliminated studies which met the following criteria: (1) only females were recruited as the study subjects, (2) either perioperative data or postoperative data was missing or not recorded, (3) reviews, letters, technical reports, case reports, comments and case series studies. Publications based on the same study (e.g. same authors, institutions, period of study) were discussed, and only the best-quality study was included.

\section{Search strategy}

We searched PubMed, EMbase, The Cochrane Library, CNKI and Clinical Trails.gov for English-language studies published before May 2019. Search terms included bariatric, laparoscopic Roux-and-Y gastric bypass, gastric bypass surgery, obesity, erectile dysfunction and sexual function. Reference lists of related articles, reviews, meta-analysis and other types of articles were also searched manually to identify additional eligible studies.

\section{Study selection}

Two reviewers independently reviewed the titles and abstracts of all retrieved studies. The full texts of studies which are deemed to be relevant studies were reviewed in details after the initial screening.

\section{Data extraction}

For each included study, we extracted data by two independent reviewers. Parameters including leading author, country, patient composition, methods for recruitment, baseline IIEF (or BSFI) score, postoperative IIEF (or BSFI) score and postoperative time point for SF assessment were recorded. We used the five-question International Index of Erectile Function (IIEF) score and BFSI score before and after bariatric surgery as the main reference index to evaluate the erectile function.

\section{Quality assessment}

We used a modified version of the methodological index for non-randomized studies' (MINORS[ [22, 23]: Table 1) checklist to assess methodological quality of the included systematic reviews. The checklist contains the following 8 aspects: (1) a clearly stated aim, (2) inclusion of consecutive patients, (3) prospective collection of data, (4) endpoints appropriate to the aim of the study, (5) unbiased assessment of the study endpoint, (6) follow-up period appropriate to the aim of the study, (7) loss to follow up less than $5 \%$, (8) prospective calculation of the study size.

\section{Data analysis}

We performed the meta-analysis by using the Cochrane Review software (Review manager v.5.3 for windows). To analyze the categorical variables, the Cochran-MantelHaenszel test was conducted and the forest plots was performed to show the results. Heterogeneity analysis uses the $\mathrm{I}^{2}$ test to define the statistic heterogeneity between each study. The heterogeneity was deemed to be acceptable and fixed model was used if the $\mathrm{I}^{2}$ was less than $50 \%$, while the heterogeneity was considered high 
Table 1 Quality assessment for all of the included studies

\begin{tabular}{|c|c|c|c|c|c|c|c|c|c|}
\hline $\begin{array}{l}\text { Included } \\
\text { studies }\end{array}$ & $\begin{array}{l}\text { 1. A } \\
\text { clearly } \\
\text { stated } \\
\text { aim }\end{array}$ & $\begin{array}{l}\text { 2. Inclusion } \\
\text { of } \\
\text { consecutive } \\
\text { patients }\end{array}$ & $\begin{array}{l}3 . \\
\text { Prospective } \\
\text { collection } \\
\text { of data }\end{array}$ & $\begin{array}{l}\text { 4. Endpoints } \\
\text { appropriate to the } \\
\text { aim of the study }\end{array}$ & $\begin{array}{l}\text { 5. Unbiased } \\
\text { assessment of } \\
\text { the study } \\
\text { endpoint }\end{array}$ & $\begin{array}{l}\text { 6. Follow-up } \\
\text { period to the } \\
\text { aim of the study }\end{array}$ & $\begin{array}{l}\text { 7. Loss to } \\
\text { follow up } \\
\text { less than } 5 \%\end{array}$ & $\begin{array}{l}\text { 8. Prospective } \\
\text { calculation of } \\
\text { the study size }\end{array}$ & $\overline{\text { Total }}$ \\
\hline $\begin{array}{l}\text { Sarwer } \\
\text { et al. [10] }\end{array}$ & 2 & 2 & 1 & 2 & 1 & 2 & 2 & 1 & 13 \\
\hline $\begin{array}{l}\text { Reis et al. } \\
{[24]}\end{array}$ & 2 & 2 & 2 & 2 & 1 & 2 & 2 & 1 & 14 \\
\hline $\begin{array}{l}\text { Ranasinghe } \\
\text { et al. [25] }\end{array}$ & 2 & 2 & 2 & 2 & 2 & 1 & 2 & 1 & 14 \\
\hline $\begin{array}{l}\text { Mora et al. } \\
\text { [26] }\end{array}$ & 2 & 1 & 2 & 2 & 2 & 2 & 2 & 1 & 14 \\
\hline Li et al. [27] & 2 & 2 & 1 & 2 & 1 & 2 & 2 & 1 & 13 \\
\hline $\begin{array}{l}\text { Groutz et al. } \\
\text { [28] }\end{array}$ & 2 & 1 & 2 & 2 & 2 & 1 & 2 & 1 & 13 \\
\hline $\begin{array}{l}\text { Efthymious } \\
\text { et al. [14] }\end{array}$ & 2 & 2 & 2 & 2 & 2 & 2 & 2 & 1 & 15 \\
\hline $\begin{array}{l}\text { Aleid et al. } \\
\text { [29] }\end{array}$ & 2 & 2 & 2 & 2 & 2 & 2 & 2 & 1 & 15 \\
\hline $\begin{array}{l}\text { ARAÚJO } \\
\text { et al. [30] }\end{array}$ & 2 & 1 & 1 & 2 & 2 & 2 & 2 & 1 & 13 \\
\hline $\begin{array}{l}\text { Dallal et al. } \\
\text { [31] }\end{array}$ & 2 & 2 & 2 & 2 & 1 & 2 & 2 & 2 & 15 \\
\hline $\begin{array}{l}\text { Goitein } \\
\text { et al. [32] }\end{array}$ & 2 & 1 & 2 & 2 & 1 & 2 & 2 & 1 & 13 \\
\hline
\end{tabular}

and the random model was used if the $\mathrm{I}^{2}$ was greater than $50 \%$.

\section{Results}

\section{Search results and characteristics of the included studies} We identified 279 studies totally. After the initial screening through the titles and abstracts, we assessed the fulltext of articles eligible for detailed assessment. Finally, 11 studies met the inclusion criteria and were included in this study. The flowchart of the procedure is shown in Fig. 1. The details of the included studies are presented in Table 2.

\section{Results of each study}

Results of each included study were illustrated in Table 3.

Sarwer et al. [11] conducted a prospective cohort study with 32 men who underwent a Roux-en-Y gastric bypass enrolled, and investigated the sexual function of individuals by using the International Index of Erectile Functioning (IIEF) and sex hormones. The results showed that there was no significant change of the sexual function from the baseline except of overall satisfaction at prospective year $3(P=0.008)$, though the men reported improvements in sexual functioning.

On the contrary, the prospective cohort study performed by Reis et al. [24]. studied 10 morbidly obese men to measure the degree of sexual function change after life style modifications (exercise and diet) for 4 months and subsequently gastric bypass. Bariatric surgery induced weight loss was found to improve erectile function quality in the research.

Ranasinghe et al. [25]. investigated the effect of weight loss and laparoscopic gastric banding surgery on sexual function among 20 obese men. The results suggested that the IIEF score achieved significant improvement after surgery while they also observed worsen erectile index $(P=0.005)$ and orgasmic function $(P=0.002)$.

In a prospective study, Mora et al. [26]. found the IIEF score increased significantly at 1 year after bariatric surgery in 39 patients. Li et al. [27]. conducted a retrospective cohort study and observed significant improvement in IIEF score after RYGB. Groutz et al. [28]. enrolled 39 consecutive obese men who underwent laparoscopic sleeve gastrectomy to investigate the effect of bariatric surgery on male's sexual function in a prospective study. The IIEF were recorded preoperatively and postoperatively. The results demonstrated that male's sexual function, including erectile function, overall intercourse satisfaction and overall satisfaction, was significantly improved after surgery. In another prospective study performed by Efthymious et al. [14], they found the bariatric surgery could significantly improve sexual function, especially in the first 6 months after surgery. In the prospective study by Aleid et al. [29]., significant improvement in male's erectile function after surgery was also reported. 


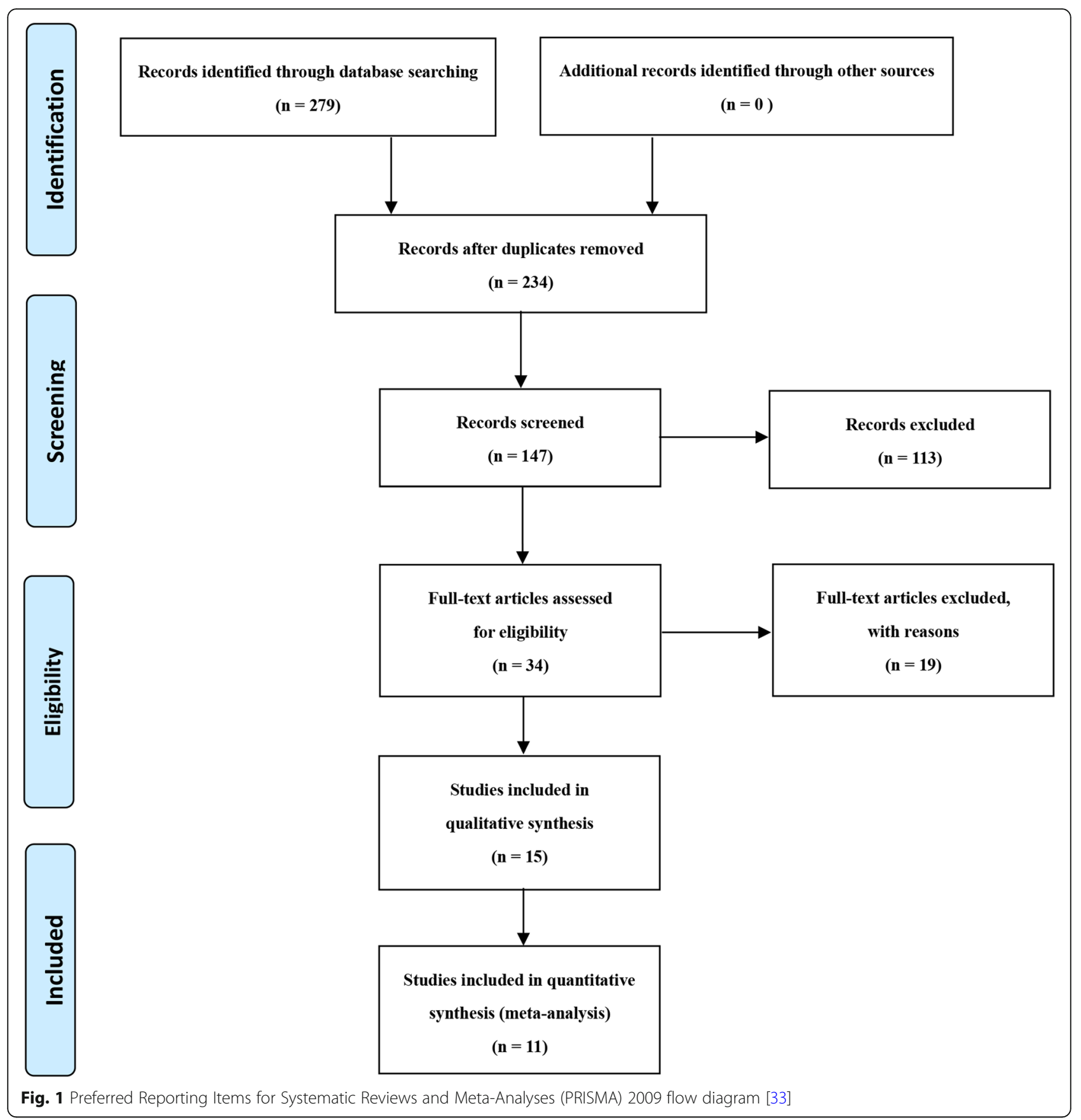

Araujo et al. [30]. evaluated the effects of Fobi-Capella gastroplasty on quality of male's sexual life and observed favorable changes in sexual function postoperatively.

Dallal et al. [31]. compared the Brief Male Sexual Function Inventory (BSFI) before and after gastric bypass surgery to measure its effect on the sexual function in morbidly obese man. In summary, the patients reported a significant improvement in all domains of BSFI scores postoperatively.

Goitein et al. [32]. found the BSFI scores increased but did not reach statistical significance $(P=0.08)$. However, general satisfaction, erection and desire were significantly improved after surgery.

\section{Meta-analysis}

The analysis was based on 370 patients from 11 studies. From the results of studies using IIEF as the index measuring erectile function $[11,14,24,26-30]$, the postoperative erectile function was significantly improved (Fig. 2a, 95\% CI 4.12-6.54, $p<0.001$ ). Improvement was also observed in the intercourse satisfaction (Fig. 2b, 95\% CI 1.19-3.94, $p=0.0002$ ), orgasmic function (Fig. 
Table 2 Characteristics of eligible studies

\begin{tabular}{|c|c|c|c|c|c|c|c|c|c|}
\hline $\begin{array}{l}\text { Study } \\
\text { (Included } \\
\text { studies) }\end{array}$ & Country & Year & $\begin{array}{l}\text { Number of } \\
\text { Patients }\end{array}$ & $\begin{array}{l}\text { Age, years } \\
( \pm S D)\end{array}$ & $\begin{array}{l}\text { Pre-op BMI, kg/m² } \\
( \pm \text { SD) }\end{array}$ & $\begin{array}{l}\text { Follow-up } \\
\text { (months) }\end{array}$ & $\begin{array}{l}\text { Surgery } \\
\text { types }\end{array}$ & $\begin{array}{l}\text { Study } \\
\text { types }\end{array}$ & $\begin{array}{l}\text { Sexual } \\
\text { function } \\
\text { index }\end{array}$ \\
\hline $\begin{array}{l}\text { Sarwer et al. } \\
\text { [10] }\end{array}$ & UK & 2012 & 31 & 48 & 45.10 & 12 & RYGB & PS & IIEF \\
\hline Reis et al. [24] & Brazil & 2009 & 10 & $36.7 \pm 11.5$ & $31.0 \pm 5.3$ & 24 & RYGB & $\mathrm{PS}, \mathrm{RCT}$ & IIEF \\
\hline $\begin{array}{l}\text { Ranasinghe } \\
\text { et al. [25] }\end{array}$ & UK & 2009 & 20 & $52.8 \pm 9.33$ & $7.3 \pm 12.67$ & 12 & LGB & RS & IIEF \\
\hline Mora et al. [26] & Spain & 2013 & 39 & $43.5 \pm 10.25$ & $30.18 \pm 5.04$ & 12 & BS & PS & IIEF \\
\hline Li et al. [27] & China & 2014 & 39 & $45.2 \pm 10.0$ & $41.2 \pm 8.5$ & 12 & RYGB & RS & IIEF \\
\hline $\begin{array}{l}\text { Groutz et al. } \\
\text { [28] }\end{array}$ & Israel & 2016 & 39 & $40.7 \pm 12.4$ & $42.8 \pm 5.6$ & 3 & LSG & PS & \|EF \\
\hline $\begin{array}{l}\text { Efthymious } \\
\text { et al. [14] }\end{array}$ & Greece & 2014 & 30 & $37.3 \pm 9.6$ & $50.66 \pm 7.9$ & 12 & $\begin{array}{l}\text { SG/RYGB/ } \\
\mathrm{BPD}\end{array}$ & PS & IIEF \\
\hline Aleid et al. [29] & UK & 2016 & 30 & $\begin{array}{l}48.9 \pm 7.0 / \\
44.1 \pm 6.9^{\#}\end{array}$ & 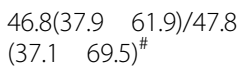 & 6 & LGB/LSG & PS & IIEF \\
\hline $\begin{array}{l}\text { ARAÚjO et al. } \\
\text { [30] }\end{array}$ & Brazil & 2009 & 21 & $20 \quad 50$ & $36 \quad 89$ & 6 & BS & PS & IIEF \\
\hline Dallal et al. [31] & America & 2008 & 97 & $47.9(19 \quad 75)$ & $51.4(36 \quad 89)$ & 19 & RYGB & PS & BSFI \\
\hline $\begin{array}{l}\text { Goitein et al. } \\
\text { [32] }\end{array}$ & Israel & 2015 & 14 & $44.8 \pm 13.9$ & $40.9 \pm 4.2$ & 67 & LSG、LRYGB & PS & BSFI \\
\hline
\end{tabular}

2c, 95\%CI $0.60-0.94, \quad p=0.03)$, overall satisfaction (Fig. 3a, 95\% CI 0.78-2.56, $\mathrm{p}=0.0002$ ), and sexual desire (Fig. 3b, 95\% CI 0.61-1.93, $p=0.0001$ ). Meanwhile, total erectile function showed a 7.21-point increasement in these studies (Fig. 3c, 95\% CI 4.33-10.10, $p<0.001$ ). In studies $[34,35]$ which used BSFI as the index measuring erectile function, favorable results showed improvement in erection (95\% CI 2.39-2.67, $p<0.001$ ), ejaculation (95\% CI 1.28-1.51, $p<0.001$ ), desire (95\% CI 1.32-1.49, $p<0.001$ ), problem assessment (95\% CI 2.06-2.34, $p<$ 0.001 ) and sexual satisfaction (95\% CI $0.60-0.76, p<$ 0.001).

\section{Disscussion}

Obesity has been a worldwide health problem and can adversely affect sexual functioning. In the Massachuster Male Aging Study [31], the average prevalence of erectile dysfunction in men who were not overweight was $13 \%$ while the altered prevalence in those who were overweight at baseline was $22 \%$. Nowadays, the bariatric surgery has become the predominant treatment for morbid obesity and is reported to be the most effective option for weight loss in the severely obese people who have excessive fat accumulation [36]. The previous studies have documented favorable clinical outcomes after bariatric surgery which can lose weight effectively and bring significant reduction in the disease-specific risk of death [18]. However, relevant researches, investigating the correlation between the bariatric surgery and male's sexual function, are insufficient. Meanwhile, the definitive causal link between bariatric surgery and male's sexual function has not been widely studied. Moreover, some relevant studies which investigated the effect of bariatric surgery on male's sexual function of morbidly obese patients were somewhat limited by lacking of sample sizes, indefinite results, and are of low credibility. Thus, we performed the meta-analysis to make a comprehensive analysis of those studies in order to investigate whether bariatric surgery contributes to improvements on male's erectile function.

To our knowledge, this is the first meta-analysis to evaluate the effect of bariatric surgery on male's sexual function with both IIEF scores and BSFI scores enrolled for comparison. Though a previous meta-analysis, by Glina et al. [34], was also performed to assess the effect of bariatric surgery on male's erectile function change, they only discussed the IIEF change and only 7 studies were enrolled for analysis.

The meta-analysis results indicate that bariatric surgery presents conspicuously effective improvements on male's sexual function by comparing IIEF scores, including erectile function, intercourse satisfaction, overall satisfaction, orgasmic function, sexual desire, total erectile function and BSFI scores, including erection, ejaculation, problem assessment, sexual satisfaction. According to Aleid et al. [29], the male's sexual function improvements after bariatric surgery could be reflected by increasement of all the IIEF domains. This could be in accordance with the study performed by Efthymious et al. [14] and other researchers [24, 26, 27]. In contrast, in studies undertaken by Ranasinghe et al. [25] and Sarwer et al. [11], which also used IIEF to assess male's 
Table 3 Results of each study

\begin{tabular}{|c|c|c|c|c|c|c|c|c|c|}
\hline Included studies & Outcomes & $\begin{array}{l}\text { Preoperative } \\
\text { Mean SD }\end{array}$ & $\begin{array}{l}\text { Postoperative } \\
\text { Mean SD }\end{array}$ & $\begin{array}{l}\boldsymbol{P} \\
\text { value }\end{array}$ & $\begin{array}{l}\text { Included } \\
\text { studies }\end{array}$ & Outcomes & $\begin{array}{l}\text { Preoperative } \\
\text { Mean SD }\end{array}$ & $\begin{array}{l}\text { Postoperative } \\
\text { Mean SD }\end{array}$ & $\begin{array}{l}\boldsymbol{P} \\
\text { value }\end{array}$ \\
\hline \multirow[t]{5}{*}{$\begin{array}{l}\text { Sarwer et al. } \\
\text { [10] }\end{array}$} & $\begin{array}{l}\text { IIEF: erectile } \\
\text { function }\end{array}$ & $19.9(11.6)$ & $21.3(10.4)$ & 0.910 & $\begin{array}{l}\text { Aleid et al. } \\
{[29]}\end{array}$ & $\begin{array}{l}\text { IIEF: erectile } \\
\text { function }^{\# 1}\end{array}$ & 13.0 & - & $<0.02$ \\
\hline & $\begin{array}{l}\text { IIEF: orgasm } \\
\text { function }\end{array}$ & $7.1(3.9)$ & $7.2(4.0)$ & $>0.99$ & & $\begin{array}{l}\text { IIEF: orgasm } \\
\text { function }\end{array}$ & 8.0 & - & $\begin{array}{l}< \\
0.004\end{array}$ \\
\hline & IIEF: sexual desire & $6.4(2.5)$ & $7.6(2.2)$ & 0.058 & & IIEF: sexual desire & 6.0 & - & $\begin{array}{l}< \\
0.002\end{array}$ \\
\hline & $\begin{array}{l}\text { IIEF: intercourse } \\
\text { satisfaction }\end{array}$ & $7.3(5.6)$ & $8.5(5.2)$ & 0.673 & & $\begin{array}{l}\text { IIEF: intercourse } \\
\text { satisfaction }\end{array}$ & 6.0 & - & $\begin{array}{l}< \\
0.004\end{array}$ \\
\hline & $\begin{array}{l}\text { IIEF: overall } \\
\text { satisfaction }\end{array}$ & $6.1(2.8)$ & $7.0(2.6)$ & 0.266 & & IIEF (total) & 64.0 & 66.5 & $\begin{array}{l}< \\
0.001\end{array}$ \\
\hline Reis et al. [24] & IIEF-5 & $19.7 \pm 6.6$ & $23.0 \pm 2.3$ & 0.0469 & $\begin{array}{l}\text { ARAÚJO } \\
\text { et al. [30] }\end{array}$ & {$[24]$} & $24.00 \pm 5.99$ & $27.85 \pm 2.45$ & 0.005 \\
\hline $\begin{array}{l}\text { Ranasinghe } \\
\text { et al. [25] }\end{array}$ & IIEF (total) & $51.36(22.17)$ & $48.17(25.34)$ & 0.712 & & $\begin{array}{l}\text { IIEF: orgasm } \\
\text { function }\end{array}$ & $9.14 \pm 1.27$ & $9.38 \pm 0.97$ & 0.234 \\
\hline \multirow[t]{6}{*}{ Mora et al. [26] } & $\begin{array}{l}\text { IIEF: erectile } \\
\text { function }\end{array}$ & $21.95 \pm 8.03$ & $25.74 \pm 6.63$ & 0.002 & & IIEF: sexual desire & $7.66 \pm 2.03$ & $8.61 \pm 1.32$ & 0.061 \\
\hline & $\begin{array}{l}\text { IIEF: orgasm } \\
\text { function }\end{array}$ & $8.08 \pm 2.30$ & $8.15 \pm 2.54$ & 0.843 & & $\begin{array}{l}\text { IIEF: sexual } \\
\text { relations }\end{array}$ & $10.09 \pm 2.58$ & $11.80 \pm 2.20$ & 0.005 \\
\hline & IIEF: sexual desire & $7.54 \pm 1.79$ & $8.15 \pm 1.33$ & 0.013 & & $\begin{array}{l}\text { IIEF: overall } \\
\text { satisfaction }\end{array}$ & $7.09 \pm 1.48$ & $8.09 \pm 1.13$ & 0.031 \\
\hline & $\begin{array}{l}\text { IIEF: intercourse } \\
\text { satisfaction }\end{array}$ & $9.67 \pm 4.19$ & $10.67 \pm 3.62$ & 0.083 & $\begin{array}{l}\text { Dallal et al. } \\
\text { [31] }\end{array}$ & BSFI: sex drive & $3.9 \pm 0.3$ & $5.3 \pm 0.3$ & $\begin{array}{l}< \\
0.001\end{array}$ \\
\hline & $\begin{array}{l}\text { IIEF: overall } \\
\text { satisfaction }\end{array}$ & $7.62 \pm 2.40$ & $8.49 \pm 2.15$ & 0.047 & & BSFI: erection & $6.4 \pm 0.5$ & $8.9 \pm 0.5$ & $\begin{array}{l}< \\
0.001\end{array}$ \\
\hline & IIEF (total) & $\begin{array}{l}54.85 \pm \\
16.59\end{array}$ & $61.21 \pm 14.10$ & 0.006 & & BSFI: ejaculation & $4.9 \pm 0.4$ & $6.3 \pm 0.4$ & $\begin{array}{l}< \\
0.001\end{array}$ \\
\hline Li et al. [27] & IIEF-5 & $17.3 \pm 5.5$ & $23.8 \pm 6.1$ & 0.004 & & $\begin{array}{l}\text { BSFI: problem } \\
\text { assessment }\end{array}$ & $7.4 \pm 0.5$ & $9.6 \pm 0.5$ & $\begin{array}{l}< \\
0.001\end{array}$ \\
\hline \multirow[t]{5}{*}{$\begin{array}{l}\text { Groutz et al. } \\
{[28]}\end{array}$} & $\begin{array}{l}\text { IIEF: erectile } \\
\text { function }\end{array}$ & $22.7 \pm 7.2$ & $26.1 \pm 6.5$ & 0.02 & & $\begin{array}{l}\text { BSFI: sexual } \\
\text { satisfaction }\end{array}$ & $1.6 \pm 0.2$ & $2.3 \pm 0.2$ & 0.002 \\
\hline & $\begin{array}{l}\text { IIEF: orgasm } \\
\text { function }\end{array}$ & $8.5 \pm 2.8$ & $9.2 \pm 1.9$ & NS & $\begin{array}{l}\text { Goitein } \\
\text { et al. [32] }\end{array}$ & BSFI: desire & $6.1 \pm 1.6$ & $7.8 \pm 2.7$ & 0.018 \\
\hline & IIEF: sexual desire & $7.8 \pm 2.1$ & $8.4 \pm 1.5$ & NS & & BSFI: erection & $4.5 \pm 0.8$ & $12 \pm 3.6$ & 0.043 \\
\hline & $\begin{array}{l}\text { IIEF: intercourse } \\
\text { satisfaction }\end{array}$ & $9.5 \pm 4.2$ & $11.5 \pm 3$ & 0.01 & & BSFI: ejaculation & $9 \pm 1.3$ & $8.3 \pm 2.6$ & 0.315 \\
\hline & $\begin{array}{l}\text { IIEF: overall } \\
\text { satisfaction }\end{array}$ & $7.9 \pm 2.5$ & $8.9 \pm 1.3$ & 0.02 & & $\begin{array}{l}\text { BSFI: problem } \\
\text { assessment }\end{array}$ & $11.3 \pm 3.7$ & $11.8 \pm 4$ & 0.042 \\
\hline \multirow[t]{5}{*}{$\begin{array}{l}\text { Efthymious } \\
\text { et al. [14] }\end{array}$} & $\begin{array}{l}\text { IIEF: erectile } \\
\text { function }\end{array}$ & $18.63 \pm 9.63$ & $24.85 \pm 8.17$ & 0.002 & & $\begin{array}{l}\text { BSFI: sexual } \\
\text { satisfaction }\end{array}$ & $2.8 \pm 0.8$ & $4.1 \pm 1.1$ & 0.0006 \\
\hline & $\begin{array}{l}\text { IIEF: orgasm } \\
\text { function }\end{array}$ & $8.33 \pm 2.64$ & $8.59 \pm 2.90$ & 0.727 & & BSFI (total) & $40.2 \pm 9.2$ & $43.9 \pm 12$ & 0.064 \\
\hline & IIEF: sexual desire & $6.29 \pm 2.27$ & $8.18 \pm 1.92$ & 0.001 & & & & & \\
\hline & $\begin{array}{l}\text { IIEF: contact } \\
\text { satisfaction }\end{array}$ & $5.15 \pm 5.26$ & $11.07 \pm 4.51$ & $\begin{array}{l}< \\
0.001\end{array}$ & & & & & \\
\hline & $\begin{array}{l}\text { IIEF: total } \\
\text { satisfaction }\end{array}$ & $5.29 \pm 2.91$ & $8.59 \pm 1.32$ & $\begin{array}{l}< \\
0.001\end{array}$ & & & & & \\
\hline
\end{tabular}

\#1(ED group)

sexual function, they found no significant improvement of erectile function among obese men undergoing bariatric surgery. Dallal et al. [31], retrospectively studied 97 obese men who had undergone gastric bypass surgery with a mean postoperative follow-up length of 19 months. In this study, they found that scores of all domains of the BSFI including sexual drive, erectile function, ejaculatory function and sexual satisfaction 


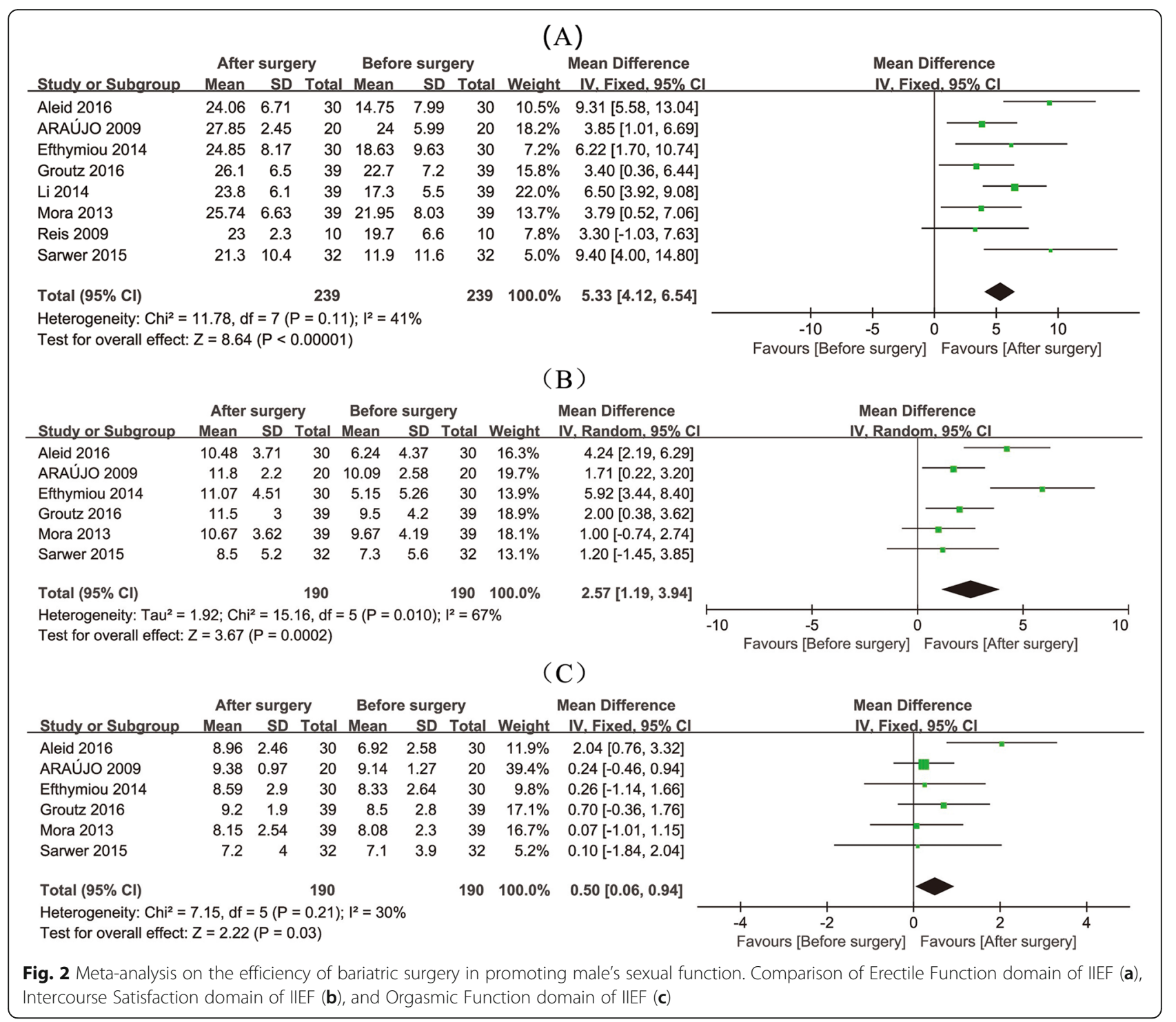

improved postoperatively. Meanwhile, the postoperative BSFI scores approached the reference controls. This is in accordance with our findings which indicated significant improvements on all domains of BFSI score.

However, the underlying mechanism of obesity-related sexual dysfunction has not been clearly elucidated. Previous studies suggested that psychological and social appearance, such as body image, depression and so on, have a negative impact on self-esteem and the tendency of avoidance and initiation to sexual behavior [35]. Negative effect of the comorbidities in obese people (diabetes, hypertension, metabolic syndrome, etc.) have already been clearly associated with sexual dysfunction [10, 31, 37]. A correlation of sex hormones to sexual function has also been confirmed, which was believed to be associated with obesity induced sexual dysfunction [38, 39]. Meanwhile, a number of biological mechanisms might account for the connection between obesity and sexual dysfunction. Obesity is a condition of inflammation and chronic oxidative stress [40]. It was suggested that obesity is linked to endothelial dysfunction and increased serum concentrations of vascular inflammatory makers [41, 42]. The visceral adipose tissue can secrete biochemical modulators and proinflammatory factors, such as IL-6, TNF- $\alpha$, angiotensinogen, angiotensin-converting enzyme and so on, which can be obviously associated with systemic and peripheral vascular inflammation and can subsequently lead to a decrease in $\mathrm{NO}$ synthase and NO activity, an increase in adhesion molecules, MCP-1 and M-CSF, finally causing endothelial dysfunction [43-45]. Moreover, the reduced adiponectin level has been confirmed to be connected with endothelial dysfunction [46, 47]. The endothelial dysfunction causes erectile dysfunction by influencing the structural integrity of the vascular bed in the penis and the progress of penile 


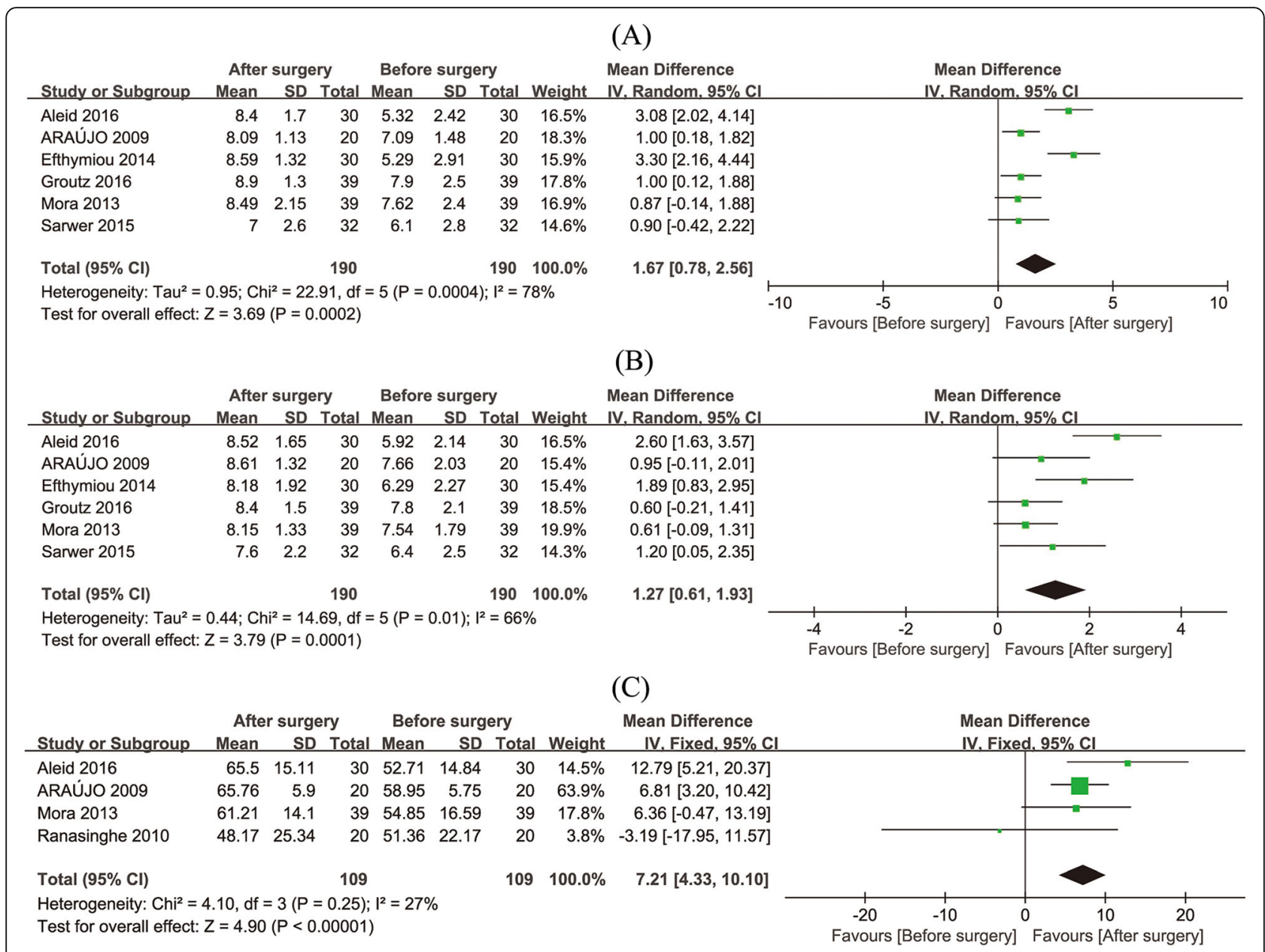

Fig. 3 Meta-analysis on the efficiency of bariatric surgery in promoting male's sexual function. Comparison of Overall Satisfaction domain of IIEF (a), Sexual Desire domain of IIEF (b), and Total Erectile Function domain (c)

engorgement by reducing the blood flow of penile [48]. It can ameliorate endothelial function by increasing vasodilation in which the endothelium plays an important role, increasing the level of activation marks of endothelium and decreasing the level of proinflammatory factor when obese patients proceed to loss weights [49]. Furthermore, the sex hormones have considerable correlation with sexual dysfunction. It is reported that the abnormalities in sex hormone regulation and production are related to sexual dysfunction in men $[50,51]$. It has been confirmed that androgens are essential in maintaining the libido and regulating erectile capacity in men [52]. But BMI is negatively associated with serum testosterone in some studies. It was reported that a reduction in free testosterone of $1.35 \mathrm{pg} / \mathrm{mL}$ and a reduction in total testosterone of 11.79 $\mathrm{ng} / \mathrm{dL}$ could be expected while the weight increases $4.5 \mathrm{~kg}$ [53]. Previous studies found a positive relationship between estradiol levels and BMI index in men [54]. And the reduction of estradiol levels is thought to be associated with weight loss. Thus, the feedback inhibition on $\mathrm{LH}$ secretion is removed and the testosterone secretion is enhanced. This mechanism was supported by European Male Aging Study, in which a negative correlation between body weight and total testosterone, free testosterone and sex hormone-binding globulin (SHBG) was reported [55].

There are some limitations of our study. (1) Language bias might limit the generalizability of the findings. (2) Patient self-report is the current standard of male sexual function assessment in this study. (3) Included sample sizes are small. (4) The indexes for evaluating male's sexual function, including IIEF score and BSFI score are simple, and are not both reported in all studies. (5) The length of follow-up is relatively short and long-term results are not available. Those limitations might lead to the analysis bias and influence the reliability of our study.

\section{Conclusions}

We found that the bariatric surgery could be effective in improving male's sexual function in obese individuals, 
with significantly improved IIEF scores and BSFI scores. These results are in accordance with the results of recent studies. With the limited number of studies evaluating the specific factor, including psychological parameter, PDE5i use, age and so on, and its influence on sexual function in obese individuals undergoing bariatric surgery, we could not make a comprehensive view on those factors. More well designed studies conducted on this topic is needed to confirm our findings.

\section{Acknowledgements}

Not applicable.

\section{Authors' contributions}

LSZ, CDH and RZJ carried out the literature search and data extraction, participated in the data analysis and drafted the manuscript. PL and LZJ participated in the study design and performed the statistical analysis. ZQ and CZY participated in the data extraction and statistical analysis. AJZ, ZXN, LLR, WQ conceived of the study and participated in its design and coordination and helped draft the manuscript. All authors read and approved the final manuscript.

\section{Funding}

This research was funded by the National Natural Science Foundation of China (Grant no. 81974098). Post-Doctor Research Project, West China Hospital, Sichuan University (Grant no.2019HXBH089). The funders had no role in the study design, data collection and analysis, decision to publish, or preparation of the manuscript.

\section{Availability of data and materials}

All data generated or analyzed during this study are included in this published.

\section{Ethics approval and consent to participate}

Not applicable.

\section{Consent for publication}

Not applicable.

\section{Competing interests}

All authors declared no competing financial interests.

\section{Author details}

${ }^{1}$ Department of Urology, Institute of Urology, West China Hospital, Sichuan University, Chengdu, Sichuan, China. ${ }^{2}$ DepartmentofUrology, Nanchong CentralHospital, The Second ClinicalMedical College,

NorthSichuanMedicalCollege (University), Nanchong, Sichuan, China. ${ }^{3}$ Department of Radiology, Chongqing Traditional Chinese Medicine Hospital, Chongqing, China.

Received: 4 July 2019 Accepted: 26 August 2020

Published online: 02 October 2020

\section{References}

1. Rew KTHJ. Erectile dysfunction. Am Fam Physician. 2016;10(94):820-7.

2. Lue TF. Erectile dysfunction. N Engl J Med. 2000:24(342):1802-13..

3. Ayta IAMJ, Krane RJ. The likely worldwide increase in erectile dysfunction between 1995 and 2025 and some possible policy consequences. BJU Int. 1999;1(84):50-6.

4. Laumann EOPA, Rosen RC. Sexual dysfunction in the United States: prevalence and predictors. Jama. 1999;6(281):537-44.

5. Clark NG, Fox KM, Grandy S, Group SS. Symptoms of diabetes and their association with the risk and presence of diabetes: findings from the study to help improve early evaluation and management of risk factors leading to diabetes (SHIELD). Diabetes Care. 2007;30(11):2868-73.

6. Dong JY, Zhang YH, Qin LQ. Erectile dysfunction and risk of cardiovascular disease: meta-analysis of prospective cohort studies. J Am Coll Cardiol. 2011; 58(13):1378-85.
7. Hedley AAOC, Johnson CL. Prevalence of overweight and obesity among US children, adolescents, and adults, 1999-2002. Jama. 2004;23(291):2847-50.

8. Inman BASJ, Jacobson DJ. A population-based, longitudinal study of erectile dysfunction and future coronary artery disease. Mayo Clin Proc. 2009;2(84): 108-13.

9. Han TSTA, O'Neill TW. Impaired quality of life and sexual function in overweight and obese men: the European male ageing study. Eur J Endocrinol. 2011;6(164):1003-11.

10. Maiorino MI, Bellastella G, Esposito K. Diabetes and sexual dysfunction: current perspectives. Diabetes Metab Syndr Obes. 2014;7:95-105.

11. Sarwer DB, Spitzer JC, Wadden TA, Rosen RC, Mitchell JE, Lancaster K, Courcoulas A, Gourash W, Christian NJ. Sexual functioning and sex hormones in persons with extreme obesity and seeking surgical and nonsurgical weight loss. Surg Obes Relat Dis. 2013;9(6):997-1007.

12. Sarwer DB, Lavery M, Spitzer JC. A review of the relationships between extreme obesity, quality of life, and sexual function. Obes Surg. 2012;22(4): $668-76$

13. Moore RH, Sarwer DB, Lavenberg JA, Lane IB, Evans JL, Volger S, Wadden TA. Relationship between sexual function and quality of life in obese persons seeking weight reduction. Obesity (Silver Spring). 2013;21(10):1966-74.

14. Efthymiou V, Hyphantis T, Karaivazoglou K, Gourzis P, Alexandrides TK, Kalfarentzos F, Assimakopoulos K. The effect of bariatric surgery on patient HRQOL and sexual health during a 1-year postoperative period. Obes Surg. 2015;25(2):310-8

15. Colquitt JL, Pickett K, Loveman E, Frampton GK. Surgery for weight loss in adults. Cochrane Database Syst Rev. 2014;8:CD003641.

16. Picot J, Jones J, Colquitt JL, Gospodarevskaya E, Loveman E, Baxter L, Clegg AJ. The clinical effectiveness and cost-effectiveness of bariatric (weight loss) surgery for obesity: a systematic review and economic evaluation. Health Technol Assess. 2009;13(41):1-190 215-357, iii-iv.

17. Jensen MD, Ryan DH, Apovian CM, Ard JD, Comuzzie AG, Donato KA, Hu FB, Hubbard VS, Jakicic JM, Kushner RF, et al. 2013 AHA/ACC/TOS guideline for the Management of Overweight and Obesity in adults. Circulation. 2014; 129(25 suppl 2):S102-38.

18. Adams TDGR, Smith SC. Long-term mortality after gastric bypass surgery. N Engl J Med. 2007;8(357):753-61.

19. Arterburn DE, Olsen MK, Smith VA, Livingston EH, Van Scoyoc L, Yancy WS $\mathrm{Jr}$, Eid G, Weidenbacher H, Maciejewski ML. Association between bariatric surgery and long-term survival. JAMA. 2015;313(1):62-70.

20. Buchwald HAY, Braunwald E. Bariatric surgery a systematic review and meta-analysis. Jama. 2004;14(292):1724-37.

21. Maggard MASL, Suttorp M. Meta-analysis: surgical treatment of obesity. Ann Intern Med. 2005;7(142):547-59.

22. Hayden JACP, Bombardier C. Evaluation of the quality of prognosis studies in systematic reviews. Ann Intern Med. 2015;6(144):427-37.

23. Whiting PRA, Reitsma JB. The development of QUADAS: a tool for the quality assessment of studies of diagnostic accuracy included in systematic reviews. BMC Med Res Methodol. 2003;3(25):1-13.

24. Reis LO, Favaro WJ, Barreiro GC, de Oliveira LC, Chaim EA, Fregonesi A, Ferreira U. Erectile dysfunction and hormonal imbalance in morbidly obese male is reversed after gastric bypass surgery: a prospective randomized controlled trial. Int J Androl. 2010;33(5):736-44.

25. Ranasinghe WK, Wright T, Attia J, McElduff P, Doyle T, Bartholomew M, Hurley K, Persad RA. Effects of bariatric surgery on urinary and sexual function. BJU Int. 2011;107(1):88-94.

26. Mora M, Aranda GB, de Hollanda A, Flores L, Puig-Domingo M, Vidal J. Weight loss is a major contributor to improved sexual function after bariatric surgery. Surg Endosc. 2013;27(9):3197-204.

27. Kun $L$, Pin Z, Jianzhong $D$, Xiaodong $H$, Haoyong $Y$, Yuqian $B$, Hongwei $Z$. Significant improvement of erectile function after roux-en-Y gastric bypass surgery in obese Chinese men with erectile dysfunction. Obes Surg. 2015; 25(5):838-44

28. Groutz A, Gordon D, Schachter P, Amir H, Shimonov M. Effects of bariatric surgery on male lower urinary tract symptoms and sexual function. Neurourol Urodyn. 2017;36(3):636-9.

29. Aleid M, Muneer A, Renshaw S, George J, Jenkinson AD, Adamo M, Elkalaawy M, Batterham RL, Ralph DJ, Hashemi M, et al. Early effect of bariatric surgery on urogenital function in morbidly obese men. J Sex Med. 2017;14(2):205-14.

30. Araujo AABA, Ferreira Mde N. Changes the sexual quality of life of the obeses submitted Fobi-Capella gastroplasty surgery. Rev Col Bras Cir. 2009; 1(36):42-8. 
31. Dallal RM, Chernoff A, O'Leary MP, Smith JA, Braverman JD, Quebbemann BB. Sexual dysfunction is common in the morbidly obese male and improves after gastric bypass surgery. J Am Coll Surg. 2008;207(6):859-64.

32. Goitein D ZA, Segev L: Bariatric surgery improves sexual function in obese patients. Isr Med Assoc J 2015, 10(17):616-619.

33. Moher D, Liberati A, Tetzlaff J, Altman DG. Preferred reporting items for systematic reviews and meta-analyses: the PRISMA statement. Int I Surg. 2010;8(5):336-41.

34. Glina FPA, de Freitas Barboza JW, Nunes VM, Glina S, Bernardo WM. What is the impact of bariatric surgery on erectile function? A systematic review and meta-analysis. Sex Med Rev. 2017:5(3):393-402.

35. Lykouras L. Psychological profile of obese patients. Dig Dis. 2008;26(1):36-9.

36. Wolfe BMMJ. Weighing in on bariatric surgery: procedure use, readmission rates, and mortality. JAMA. 2005;15(294):1960-3.

37. Miner MEK, Guay A. Cardiometabolic risk and female sexual health: the Princeton III summary. J Sex Med. 2012;3(9):641-51.

38. Gosman GG, Katcher HI, Legro RS. Obesity and the role of gut and adipose hormones in female reproduction. Hum Reprod Update. 2006;12(5):585-601.

39. Meikle AW. The relationships between sex hormones and sexual function in middle-aged and older European men. Yearb Endocrinol. 2012;2012:299-300.

40. Higdon JV, Frei B. Obesity and oxidative stress: a direct link to CVD? Arterioscler Thromb Vasc Biol. 2003;23(3):365-7.

41. Bastard JPJC, Bruckert E. Elevated levels of interleukin 6 are reduced in serum and subcutaneous adipose tissue of obese women after weight loss. J Clin Endocrinol Metab. 2000;9(85):3338-42.

42. Ziccardi P, Nappo F, Giugliano G, Esposito K, Marfella R, Cioffi M, D'Andrea F, Molinari AM, Giugliano D. Reduction of inflammatory cytokine concentrations and improvement of endothelial functions in obese women after weight loss over one year. Circulation. 2002;105(7):804-9.

43. Hutley L, Prins JB. Fat as an endocrine organ: relationship to the metabolic syndrome. Am J Med Sci. 2005;330(6):280-9.

44. Lyon CJ, Law RE, Hsueh WA. Minireview: adiposity, inflammation, and atherogenesis. Endocrinology. 2003;144(6):2195-200.

45. Chudek JWA. Adipose tissue, inflammation and endothelial dysfunction. Pharmacol Rep. 2006;58(Suppl (58)):81-8.

46. Pietilainen KH, Kannisto K, Korsheninnikova E, Rissanen A, Kaprio J, Ehrenborg E, Hamsten A, Yki-Jarvinen H. Acquired obesity increases CD68 and tumor necrosis factor-alpha and decreases adiponectin gene expression in adipose tissue: a study in monozygotic twins. J Clin Endocrinol Metab. 2006;91(7):2776-81.

47. Pietilainen KHBR, Rissanen A. Effects of acquired obesity on endothelial function in monozygotic twins. Obesity (Silver Spring). 2006;5(14):826-37.

48. Traish AM, Feeley RJ, Guay A. Mechanisms of obesity and related pathologies: androgen deficiency and endothelial dysfunction may be the link between obesity and erectile dysfunction. FEBS J. 2009;276(20):5755-67.

49. Kirby MJG, Simonsen U. Endothelial dysfunction links erectile dysfunction to heart disease. Int J Clin Pract. 2005;2(59):225-9.

50. Jarow JPK, Koritnik DR. Effect of obesity and fertility status on sex steroid levels in men. Urology. 1993;2(42):171-4.

51. Pasquali RCF, Cantobelli S. Effect of obesity and body fat distribution on sex hormones and insulin in men. Metab Clin Exp. 1991;1(40):101-4.

52. Botella-Carretero Jl, Balsa JA, Gomez-Martin JM, Peromingo R, Huerta L, Carrasco M, Arrieta F, Zamarron I, Martin-Hidalgo A, Vazquez C. Circulating free testosterone in obese men after bariatric surgery increases in parallel with insulin sensitivity. J Endocrinol Investig. 2013;36(4):227-32.

53. Hammoud A, Gibson M, Hunt SC, Adams TD, Carrell DT, Kolotkin RL, Meikle AW. Effect of roux-en-Y gastric bypass surgery on the sex steroids and quality of life in obese men. J Clin Endocrinol Metab. 2009;94(4):1329-32.

54. Vermeulen A. Decreased androgen levels and obesity in men. Ann Med. 1996; $1(28): 13-5$.

55. Camacho EM, Huhtaniemi IT, O'Neill TW, Finn JD, Pye SR, Lee DM, Tajar A, Bartfai G, Boonen S, Casanueva FF, et al. Age-associated changes in hypothalamic-pituitary-testicular function in middle-aged and older men are modified by weight change and lifestyle factors: longitudinal results from the European male ageing study. Eur J Endocrinol. 2013;168(3):445-55

\section{Publisher's Note}

Springer Nature remains neutral with regard to jurisdictional claims in published maps and institutional affiliations.

Ready to submit your research? Choose BMC and benefit from:

- fast, convenient online submission

- thorough peer review by experienced researchers in your field

- rapid publication on acceptance

- support for research data, including large and complex data types

- gold Open Access which fosters wider collaboration and increased citations

- maximum visibility for your research: over $100 \mathrm{M}$ website views per year

At $\mathrm{BMC}$, research is always in progress.

Learn more biomedcentral.com/submissions 